Available online @ https://jjem.jnnce.ac.in

https:www.doi.org/10.37314/JJEM.2020.040204

Indexed in International Scientific Indiexing (ISI)

Impact factor: 1.025 for 2018-19

Published on: 30 March 2020

\title{
Design and Analysis of Hybrid Solar Cell for e-Vehicle Charging
}

\author{
Shankara Murthy A G ${ }^{1 *}$, Devi Prasad M.N², Varun G Guddadar ${ }^{3}$ \\ ${ }^{1 *}$ Professor, MED, Bapuji Institute of Engineering and Technology, Davangere, India \\ ${ }^{2}$ Mechanical Engineering Department, Jain College of Engineering and Technology, Hubli, India \\ ${ }^{3}$ Accenture Bangalore, India
}

agsiitr@gmail.com,dnmirashi@gmail.com,varunuguddadar@gmail.com

\begin{abstract}
This work aims to develop and analyze Hybrid Solar cell which is the combination of Dye -sensitized solar cell (DSSC) and photovoltaic (PV) cell. PV cells are more efficient during day time and generating good amount of electricity but less effective during low light conditions due to the weakness of being a minority carrier device. To overcome this DSSC are used which are capable of being effective during both high and low light conditions because electrons are easily ejected from dye compared to that of P-N junction. DSSC provides a technically and economically viable alternative energy to present $P-N$ junction $P V$ cells. In this work Natural Dyes are used because they are easily available and economically viable. Hybrid solar cell is developed using PTC CREO software virtually for visual representation. Performance analysis of Hybrid solar cells is obtained using MATLAB software at various conditions. Results of Hybrid solar cell are compared for the combination of different dyes. By this Hybrid solar cell generates power throughout the day, which many be used for charging e-vehicles.
\end{abstract}

Keywords: DSSC, PV cell, Hybrid Solar cell, Natural Dyes, TiO2 plate

\section{Introduction}

Automobile vehicles that are in the market today cause pollution and fuel cost is also increasing day by day. In order to compensate the fluctuating fuel cost and reducing the pollution a good remedy to the transportation system is needed. Due to ignition of the hydrocarbon fuels in the vehicle, sometime difficulties such as wear and tear may be high and more attention is needed for proper their maintenance $[1,2]$. Current vehicles are easy to handle and no fuel cost to the other existing vehicles. Hence a need for a change in the existing alternative system which can produce higher efficiency at minimum cost. So this is very much useful, since it is provided with good quality of energy source with simple operating mechanism. Hence "each and every drop of fuel saves our economy and meet the needs" is the saturation point that is to be attained as soon as possible. This alternate energy must be much more convenient in availability and usage. The most effective and promising energy source against the natural resource is solar energy which produces green energy and suitable for future automobile vehicles. The solar energy is one of the solutions for this problem. Overall solar energy to current conversion up to efficiencies over 15 to $20 \%$ has been reached. But the PV cells are not capable of producing energy during low light conditions. Dye-sensitized solar cells (DSCs) have attracted much attention in recent years, because of their good photovoltaic performance, specifically under low-light conditions, as well as their flexibility in terms of colors and appearance, their relatively simple fabrication procedures and their potential low cost. In contrast to the conventional systems where the semiconductor assumes both the task of light absorption and charge carrier transport, but these two functions are separated here. Light is absorbed by a sensitizer, which is anchored to the surface of a wide band semiconductor. Charge separation takes place at the interface via photo-induced electron injection from the dye in to the conduction band of the solid. Charge 
carriers are transported in the conduction band of the semiconductor to the charge collector. The use of sensitizers having a broad absorption band is conjunction with oxide films of Nano crystalline morphology permits to harvest a large fraction of sunlight nearly quantitative conversion of incident photon into electric current is achieved over a large spectral rangeextending from the Ultraviolet (UV) to the near Infrared (IR) region [3, 4]. The first embodiment of modem day DSSC dates back to late 1980s. However, the fundamental work of Graetzel and O'Regan in 1991 proved that DSSC can be a feasible alternative energy source. From 2009 to 2013, the efficiency of Solid State DSSCs has dramatically increased from $4 \%$ to $15 \%$. Michael Graetzel fabricated Solid State DSSCs with $15.0 \%$ efficiency. As on 2019 , the world record for solar cell efficiency is $46.0 \%$ using multi-junction concentrator solar cells developed in Germany which is above the standard rating of $37.0 \%$ for polycrystalline PV or thin-film solar cells. DSSCs offer transparency, low cost and high power conversion efficiencies under cloudy and light conditions. Hence, this paper gives an insight on design and analysis of hybrid solar cell which is the combination of PV cell and DSSC to harness the hybrid energy which is more effective and efficient to energize e-vehicles in future [5].

\section{Design of Hybrid Solar Cells}

\subsection{Conceptual Design}

Conceptual design and schematic diagram of DSSCs cell is as shown in Figure 1 and Figure 2. Also the conceptual design of hybrid solar cell model is shown in the Figure 3. Using MATLAB tool [6], DSSC, hybrid solar cell with various combinations of Natural dyes were modeled and analyzed as per the design standardsl.

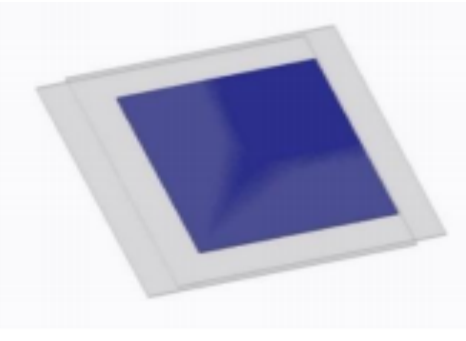

Figure 1: Conceptual Image of DSSC [7]

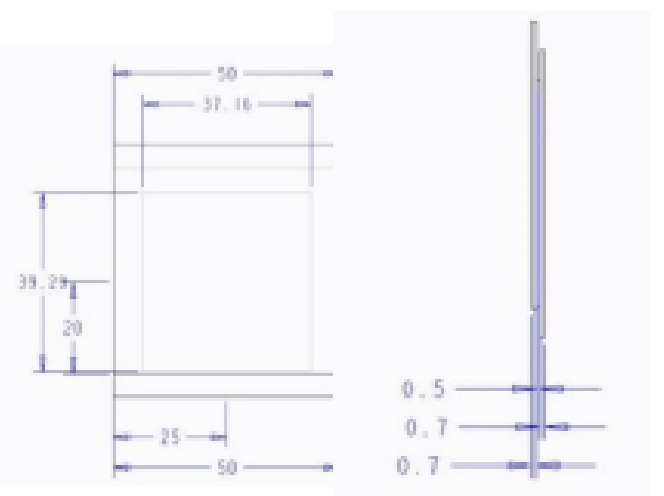

Figure 2: Schematic Diagram of DSSC [7]

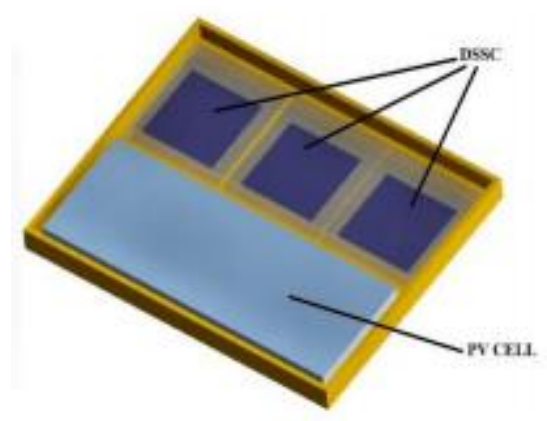

Figure 3: Conceptual Image of Hybrid Solar Cell

\subsection{Materials and Methodology}

Following materials are used for developing the DSSC and hybrid solar cell. Methodology is used for the analysis of designed cells is as represented in the flowchart (Figure 4).

\section{A. ITO Glass Plates}

i. Dimension: 50x50x0.7mm.

ii. Resistivity: $\leq 10 \mathrm{ohms} / \mathrm{sq}$.

iii. Transmittance: $\geq 86 \%$ 


\section{B. Nano Titania (TiO2)}

Crystal Size: $25 \pm 5$ with Purity $99.9 \%$

C. $5 \%$ Nitric Acid and $15 \%$ Acetic Acid

D. Iodine Solution $(0.5 \mathrm{M} \mathrm{KI}+0.05 \mathrm{MI} 2)$

E. Ethanol,

F. TiO2 Nano Powder

G. De-ionized Water.

H. Liquid Electrolyte Solution,

I. Binder Clips

J. PV Cell

K. Lithium Ion Battery

L. E-Vehicle chasis.

N. Natural Dyes
i. Coffee

ii. Turmeric

iii. Mixture of coffee and turmeric

iv. Phyllanthus reticulatus poir (Karihuli)

v. Piper crocatum (Red betel leaf),

vi. Melaleuca leucadendra

(Weeping paperback/ Cajeput).

\subsection{Simulation on the Performance of Dye Senstized Solar Cell Incorporated with $\mathrm{TiO}_{2}$ layer}

In this work, characteristics of the DSSC has been simulated using MATLAB based on $\mathrm{TiO}_{2}$ by modifying the internal parameters $(\boldsymbol{\Phi}, \boldsymbol{\tau}, \boldsymbol{\alpha}$ ,m,) and external parameters [6]. The simulation has been performed to determine the performance of natural dyes of coffee, turmeric, mixture of coffee and turmeric, phyllanthus reticulates pair (Karihuli), piper crocatum (Red betel leaf) and melaleuca leucadendra

(weeping paperback/ Cajuput) in terms of the change due to the intensity of solar radiation and temperature by displaying the $\mathrm{I}-\mathrm{V}$ and $\mathrm{P}-\mathrm{V}$ curve characteristics $[8,9,10,11]$.This simulation was performed to obtain the performance of DSSC using various natural dyes to determine the effect of work temperature and solar light intensity between 08.00 to 17.00 Hours. The results of the analysis are plotted using graphs representing the relationship between current density and voltage (I-V) and the maximum Power Vs. voltage $(\mathrm{P}-\mathrm{V})$ produced by DSSC were obtained through simulation. The simulation process was carried out on the characteristics of natural dye by initially collecting parameters to material's model flowchart as shown in Figure 4 and the input parameters are listed in Table 1. The simulation has produced highest DSSC performance by using natural dye from melaleuca leucadendra with a maximum voltage, current density and power of 0.7882 $\mathrm{V}, 0.0032 \mathrm{~A} / \mathrm{cm} 2$ and $0.0015 \mathrm{~W}$ respectively using a cell area of $1.5 \times 1.5 \mathrm{~cm}[2]$. The DSSC produced maximum power of $0.0013 \mathrm{~W}$ at 12.00 o'clock in the afternoon. Therefore some of these natural dyes have indicated the highest potential of becoming low-cost photosensitizer which is abundantly available and eco-friendly [4].

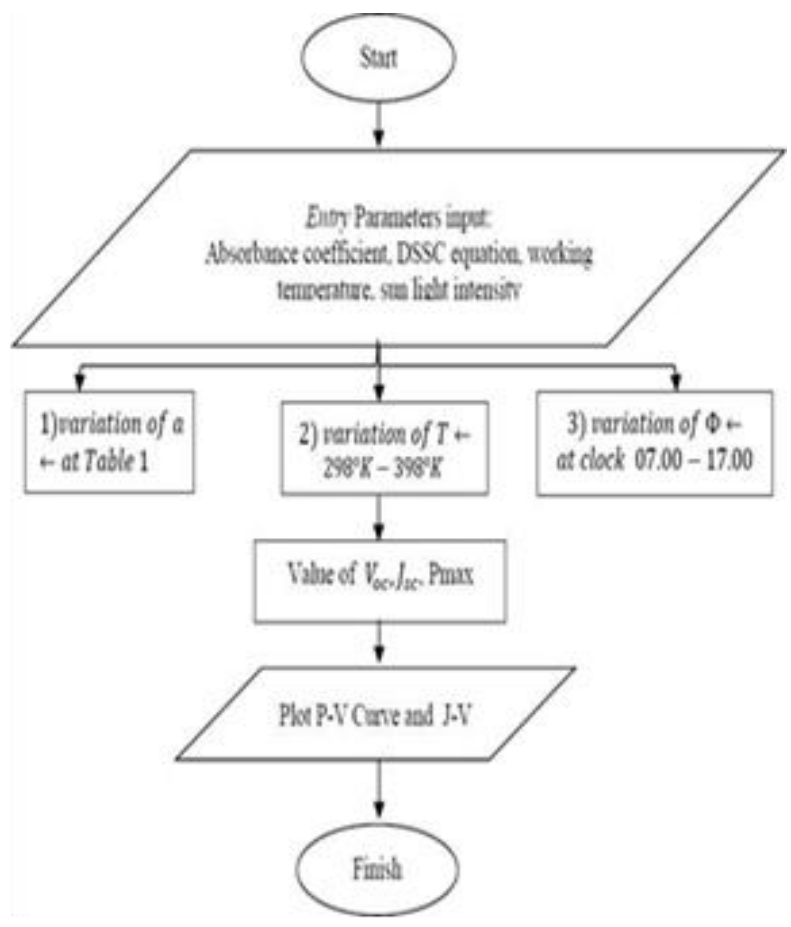

Figure 4: Flowchart of the Simulation Process [9]. 
Table 1: Input Parameters

\begin{tabular}{|c|c|c|}
\hline Parameters & Value & Information \\
\hline $\mathrm{k}$ & $1.381 \times 10^{-23} \mathrm{JK}$ & Boltzmann constant \\
\hline$q$ & $1.602 \times 10^{-19} \mathrm{C}$ & Electron charge \\
\hline L & $2.2361 \times 10^{-3} \mathrm{~cm}$ & $\begin{array}{l}\text { Length of electron } \\
\text { diffision }\end{array}$ \\
\hline$d$ & $5 \times 10^{-4} \mathrm{~cm}$ & Length of Tiop \\
\hline$a$ & 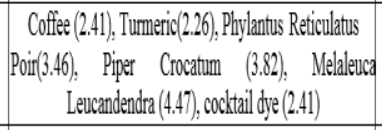 & $\begin{array}{l}\text { Absorption } \\
\text { coefficient }\end{array}$ \\
\hline m & 4.5 & Ideal factor \\
\hline D & $2.3 \times 10^{-5} \mathrm{~cm}^{2} / \mathrm{s}$ & Diffusion coefficient \\
\hline no & 1016 electron $\mathrm{cm}^{2}$ & Electron concentration \\
\hline$t$ & $0.01 \mathrm{~s}$ & Lifetime \\
\hline$\phi$ & $1 \times 10^{17} \mathrm{~cm}^{2} \mathrm{~s}^{1}$ & Sunlight intensity \\
\hline $\mathrm{T}$ & $300 \mathrm{~K}$ & Temperature \\
\hline
\end{tabular}

\subsection{Simulation procedure}

The equations (1), (2) and (3) related to the system model are as follows, where Jsc is short-circuited current density, Voc is open circuit voltage, $\mathrm{J}$ is current density and $\mathrm{V}$ is voltage produced by DSSC [10].

$$
\begin{aligned}
& J_{S C}=\frac{q \Phi L \alpha}{1-L^{2} \alpha^{2}}\left[-L \alpha+\tanh \left(\frac{d}{L}\right)+\frac{L \alpha \exp (-d a)}{\cosh \left(\frac{d}{L}\right)}\right] \\
& V_{O C}=\frac{k T m}{q} \ln \left[\frac{L J_{S C}}{q D n_{0} \tanh \left(\frac{d}{L}\right)}+1\right] \\
& J=J_{S C}-\frac{q D n_{0}}{L} \tanh \left(\frac{d}{L}\right)\left[\exp \left(\frac{q V}{k T m}\right)-1\right]
\end{aligned}
$$

\subsection{Simulation of the PV Cells}

The mathematical model of solar PV module which is based on the fundamental building blocks of the current source, diode, series and parallel resistors was developed in step by step procedure under MATLAB/SIMULINK system using the above-described modelling. Figure 5 depicts the steps involved in PV cell modelling. For simulation JAP6-72-320/4BB PV solar module has been selected as a reference model and provides input parameters for modeling
(Datasheet JAP6-72-320/4BB, JA Solar). The final model of PV cell transforms the solar energy into electricity and provides the characteristics curves for given radiation and temperature as input parameters given in Table 2.

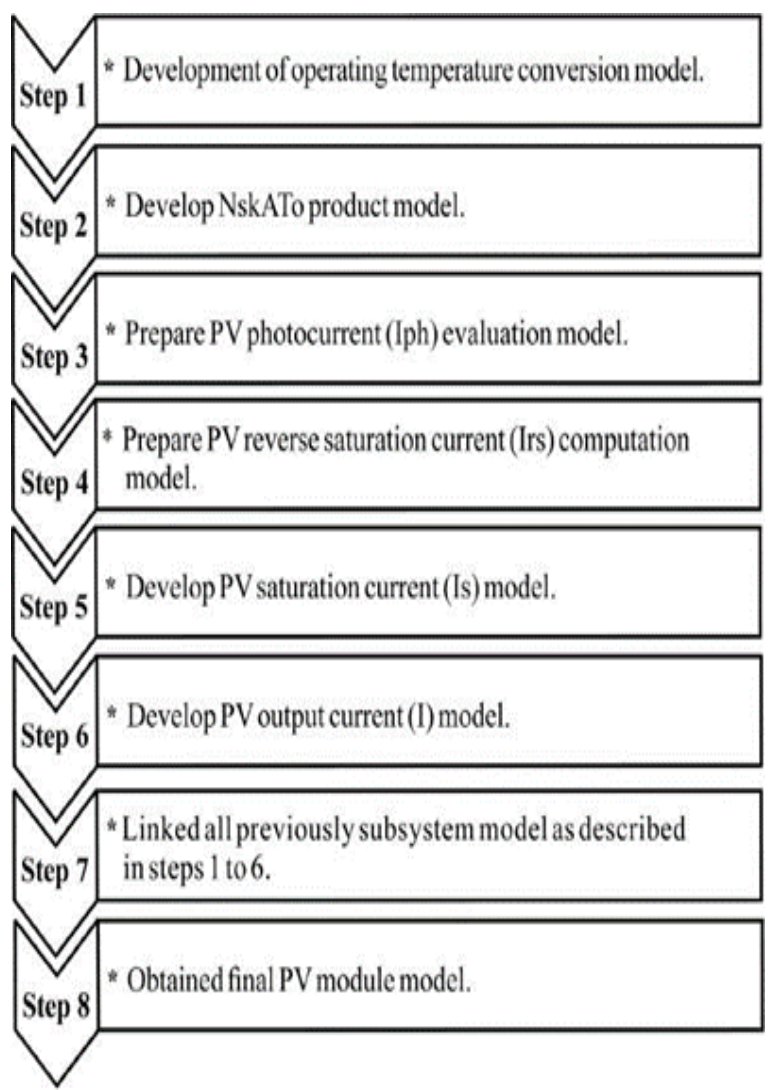

Figure 5: Photovoltaic modelling steps involved in Simulink [10]

\begin{tabular}{|c|c|c|c|}
\hline S. No. & Parameters & Variables & Values \\
\hline 1. & Maximum power at STC $(\mathrm{Pm})$ & $\mathrm{Pm}$ & $320 \mathrm{~W}$ \\
\hline 2. & Maximum power voltage (Vmp) & $\mathrm{Vm}$ & $37.38 \mathrm{~V}$ \\
\hline 3. & Maximum power current (Imp) & Im & $8.56 \mathrm{~A}$ \\
\hline 4. & Open circuit voltage (Voc) & Voc & $46.22 \mathrm{~V}$ \\
\hline 5. & Short-circuit current (ISc) & Isc & $9.06 \mathrm{~A}$ \\
\hline 6. & Total series cells & Ns & 72 \\
\hline 7. & Total parallel cells & $\mathrm{Np}$ & 1 \\
\hline 8. & Ideality factor of diode & A & 1.3 \\
\hline 9. & $\begin{array}{l}\text { Cell short circuit current temperature } \\
\text { coefficient of Isc }\end{array}$ & $\mathrm{Ki}$ & $0.058 \%$ C C \\
\hline 10. & Reference temperature & Tref & $25 \circ \mathrm{C}$ \\
\hline 11. & Solar Irradiance & Gref & 1000 at STC \\
\hline
\end{tabular}

Table 2: Electrical Parameters of JAP6-72-320/4BB Solar PV Module

Source: Data sheet JAP6-72-320/4BB, JA solar. 


\section{Calculations}

\section{A. DSSC under Ideal conditions:}

The value of sunlight intensity is kept constant in equation 1 and 2 , i.e., $\phi=1 \times 10^{17} \mathrm{~cm}^{-2} \mathrm{~s}^{-1}$

$>$ The Voltage generated in DSSC from the simulation software for dimension $1.5 \times 1.5 \mathrm{~cm}$ is $0.7882 \mathrm{~V}$

$>$ Voltage generated in DSSC for dimension $5 \times 15 \mathrm{~cm}$ is $\mathrm{Vdssc}=8.7578 \mathrm{~V}$

\section{B. DSSC under Practical/real conditions:}

The value of maximum sunlight intensity is substituted from Table 4 in equation 1 and 2 i.e. $=867.8 \mathrm{w} / \mathrm{m}^{2}$ at $12.00 \mathrm{PM}$

\section{Voltage:}

The Voltage generated in DSSC by simulation for dimension $1.5 \times 1.5 \mathrm{~cm}$ is $0.4287 \mathrm{~V}$,

Then by calculation, the voltage generated in DSSC for dimension $5 \times 15 \mathrm{~cm}$ ( 3 cells), $\operatorname{VDSSC}=14.29 \mathrm{~V}$

\section{Current:}

$>$ The Current generated in DSSC for dimension $1.5 \times 1.5 \mathrm{~cm}$ is $\mathbf{0 . 1 4} \mathbf{m A}$.

$>$ The Current generated in DSSC for $5 \times 5 \mathrm{~cm}$ ( 1 cell) is $\mathbf{1 . 5 5} \mathbf{~ m A}$,

$>$ Then the current generated for three cells, IDSSC $=1.55 \times 3=4.65 \mathrm{~mA}$, Power: PDSSC $=$ VI $=14.29 \times 4.65 \times 10-3 \mathrm{~W}$

\section{E. Power:}

PDSSC $=$ VI $=14.29 \times 4.65 \times 10^{-3}=0.06644 \mathrm{~W}$.

\section{F. Calculation for PV cell:}

$>$ Voltage generated from the PV cell according to the simulation software for $195 \times 95 \mathrm{~cm}$ is $37 \mathrm{~V}$

$>$ Current generated from the PV cell according to the simulation software for $195 \times 95 \mathrm{~cm}$ is $9.06 \mathrm{~A}$

By calculation the voltage and current generated by PV cell of dimension $5 \times 15 \mathrm{~cm}$ are,

$\mathrm{VPV}=21.3336 \mathrm{~V}$ and IPV $=1.058 \mathrm{~A}$ and

Power, PPV $=$ VI $=21.3336 \times 1.058=1.2375 \mathrm{~W}$

G. Calculation for Hybrid Solar cell:

Total current $\mathrm{I}=4.56 \mathrm{~mA}+58 \mathrm{~mA}=\mathbf{6 2 . 5 6}$ mA

Total voltage $\mathrm{V}=14.29+21.336=\mathbf{3 5 . 6 2} \mathbf{V}$

Total power $\mathrm{P}=1.2375+0.0644=\mathbf{1 . 3 0 4} \mathbf{W}$

\section{Results and Discussion}

\subsection{Results obtained for the Dye Sensitized Solar Cell Incorporated with TiO2 Layer}

The gap between the conduction band and the valence band is called band gap energy. This band gap energy is used to analyze the performance of DSSC related to solar energy or wavelength of sunlight absorbed by the natural dye in DSSC. Using [8] the value of the wavelength of sunlight absorbed by the natural dye is calculated using Equation 4. From the calculation results, the relationship between wavelength and photon energy absorbed by the natural dye is presented in Table 3 .

Table 3: Wave length and natural dye's photon energy

\begin{tabular}{|c|c|c|}
\hline $\begin{array}{c}\text { Variation } \\
\text { of Dye }\end{array}$ & $\begin{array}{c}\text { Wavelength } \\
(\mathbf{n m})\end{array}$ & $\begin{array}{c}\text { Photon } \\
\text { Enegy } \\
(\mathbf{e V})\end{array}$ \\
\hline $\begin{array}{c}\text { Phyllanthus } \\
\text { Reticulatus } \\
\text { Poir }\end{array}$ & 350 & 3.55 \\
\hline $\begin{array}{c}\text { Piper Croca- } \\
\text { tum }\end{array}$ & 410 & 3.03 \\
\hline Coffee & 450 & 2.76 \\
\hline Tumeric & 480 & 2.58 \\
\hline $\begin{array}{c}\text { Melaleuca } \\
\text { Leucadendra }\end{array}$ & 520 & 2.39 \\
\hline $\begin{array}{c}\text { Cocktail (Cof- } \\
\text { fee+ turmeric) }\end{array}$ & 450 & 2.76 \\
\hline
\end{tabular}

From Table 3, it indicated that the larger the wavelength of the sunlight absorbed by the natural dye the smaller the absorbed energy [8] or else a natural dye that absorbs the large 
wavelengths has small bandgap energy. This is suitable with the equation (4) which states that the wavelength is inversely proportional to the photon's energy. The lowest bandgap energy of Melaleuca Leucadendra which was equal to $2.39 \mathrm{eV}$ is suitable with the bandgap energy of TiO2 semiconductors used as a photo electrode DSSC in this work. . The larger bandgap between the dye energy gap and the large bandgap $\mathrm{TiO} 2$ energy helps electrons to move rapidly from the valence band to the conduction band and only requires less energy for electron recombination and increases DSSC efficiency [2].

The first simulation of this work is examining the performance of DSSC using various natural dyes prepared in the laboratory. The natural dye candidates are made from local ingredients such as coffee, turmeric, cocktail (coffee and turmeric), phyllanthus reticulatus poir, piper crocatum, and melaleuca leucadendra. All parameters of input are listed in Table 1. From the simulation results with the use of equations (1), (2) and (3) the performance of DSSC using some natural dye candidates that obtained the maximum voltage, current density and power are presented in Table 4. It is observed that melaleuca leucadendra (f) has highest Voc, Jsc and power than the other natural dyes due to the higher absorbance coefficient of melaleuca leucadendra (f) compared to other natural dyes. The absorbance coefficient of natural dye is the ability to absorb the sunlight. The J-V and P-V curves are shown in Figure 6 and 7 respectively.

Table 4: DSSC performance based on various local natural dye

\begin{tabular}{|c|c|c|c|c|}
\hline Combination of Dyes & Absorbance Coefficient & Voc, V & $\mathrm{Jsc} \mathrm{mA} / \mathrm{cm}^{2}$ & $P_{\max }$ \\
\hline Coffee (b) & $2.41[4]$ & 0.7220 & 0.0018 & $7.6 \times 10^{-4}$ \\
\hline Tumeric (a) & $2.26[4]$ & 0.7150 & 0.0017 & $7.1 \times 10^{-4}$ \\
\hline Cocktail (Coffeet Tumeric)(c) & $2.41[4]$ & 0.7220 & 0.0018 & $7.6 \times 10^{-4}$ \\
\hline Phyllanthus Reticulatus Poir (d) & $3.46[13]$ & 0.7613 & 0.0025 & 0.0012 \\
\hline Piper Crocatum (e) & $3.82[13]$ & 0.7710 & 0.0027 & 0.0013 \\
\hline Melaleuca Levccadendra (f) & $4.47[13]$ & 0.7882 & 0.0032 & 0.0015 \\
\hline
\end{tabular}

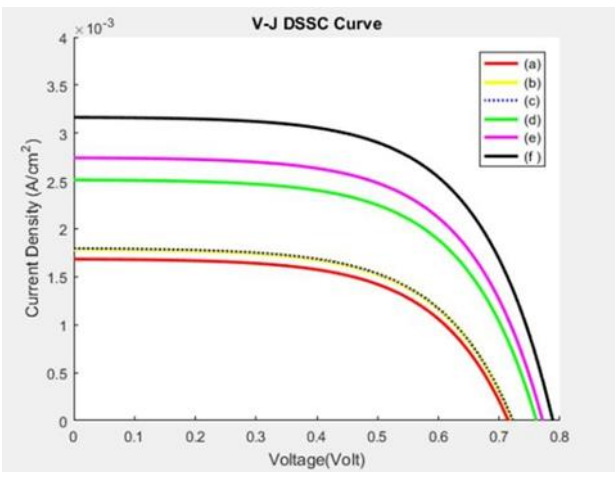

Figure 6: J-V Curve on Various Local Natural Dyes, (a) Tumeric,(b) Coffee, (c) Cocktail Dye (Coffee + Tumeric), (d) Phyllanthus Reticulatus Poir, (e) Piper Crocatum, (f) Melaleuca Leucadendra[9]

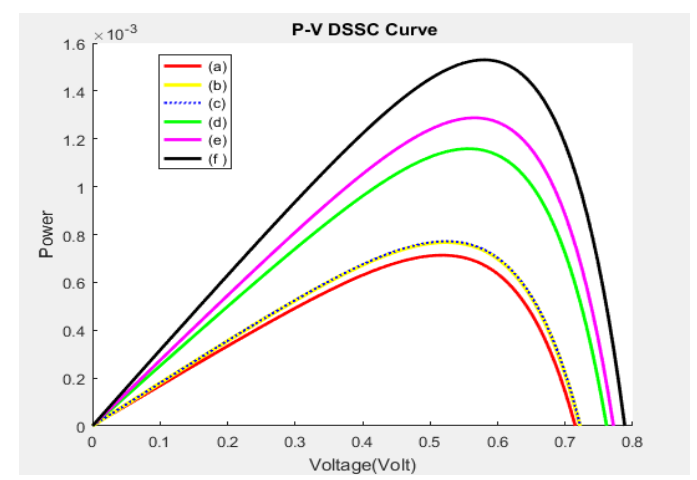

Figure 7: P-V Curve on Various Local Natural Dyes, a) Tumeric, (b) Coffee, (c) Cocktail Dye (Coffee + Tumeric), (d) Phyllanthus Reticulatus Poir, (e) Piper Crocatum, (f) Melaleuca Leucadendra[9].

\subsection{Results obtained for the Simulation of the PV Cell}

Solar PV module model is developed using MATLAB/SIMULINK based on the mathematical equations of solar cells. The JAP6-72/320/4BB module parameters from manufacturer datasheet are incorporated during simulation block model and consider as reference module. The final Solar PV model simulated results are depicted in Figure 8. The output results of current, voltage and power is due to the variation in radiation and temperature as input parameters. The final PV solar model is evaluated in standard test conditions (STC), which is kept same as in the world and performed in irradiance of $1000 \mathrm{~W} / \mathrm{m}^{2}$ under a temperature of $25^{\circ} \mathrm{C}$ in air mass of 1.5. Simulation of the solar PV model executes the $\mathrm{I}-\mathrm{V}$ and $\mathrm{P}-\mathrm{V}$ characteristics curves. Generally a good agreement was observed 
between various performance parameters results of reference model and simulated PV model at STC as illustrated in Table 5. The relative error for all the parameters of solar PV model is comprised between 0 to $1.65 \%$.

Table 5: Comparison of reference model values and simulation model values at SYC

\begin{tabular}{|c|c|c|c|}
\hline Parameters & $\begin{array}{c}\text { Parameters of JAP6-72/320/4BB } \\
\text { datasheet -reference model }\end{array}$ & $\begin{array}{c}\text { Parameters from } \\
\text { simulation of the model }\end{array}$ & Relative error (\%) \\
\hline Pmax (W) & 320 & 319.9996 & 0.000125 \\
\hline $\operatorname{Voc}(\mathrm{V})$ & 46.22 & 46.2063 & 0.030 \\
\hline $\operatorname{Isc}(\mathrm{A})$ & 9.06 & 9.06 & 0 \\
\hline $\operatorname{Vmp}(\mathrm{V})$ & 37.38 & 38 & 1.63 \\
\hline $\operatorname{Imp}(\mathrm{A})$ & 8.56 & 8.421 & 1.65 \\
\hline Efficiency $(\eta \%)$ & 16.51 & 16.51 & 0 \\
\hline
\end{tabular}

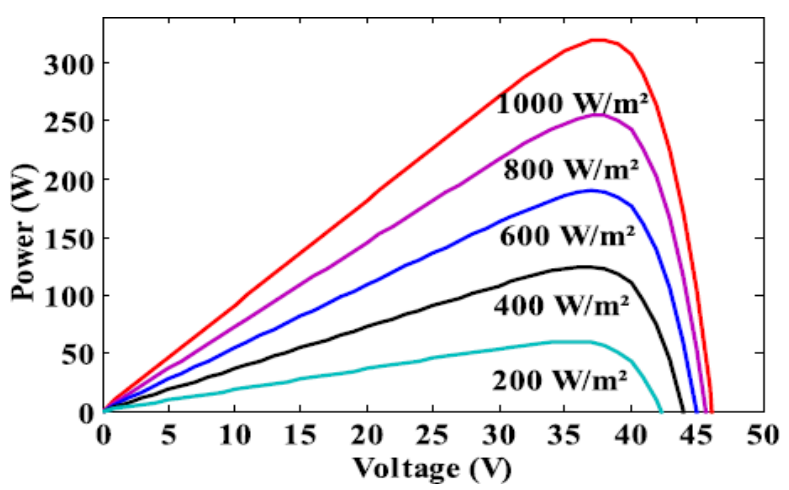

Figure 8: I-V characteristics for varying irradiance at Constant temperature

The effect on solar PV model I-V and P-V characteristics curves is depicted in Figures 8 and 9 by varying the intensity of irradiance from 200 to $1000 \mathrm{~W} / \mathrm{m}^{2}$ at constant temperature of $25^{\circ} \mathrm{C}$. It is observed that current remains constant with rising voltage up to $30 \mathrm{~V}$ after which it decreases. Moreover, the current increases while rising the irradiance intensity. This demonstrates that irradiance has a substantial effect on short circuit current, at the same time open circuit voltage is quite low as shown in Figure 9. The maximum power evidence exists on power performance curves. The generation of power by solar PV model is increased by increasing the intensity of solar irradiance as shown in Figure 9.

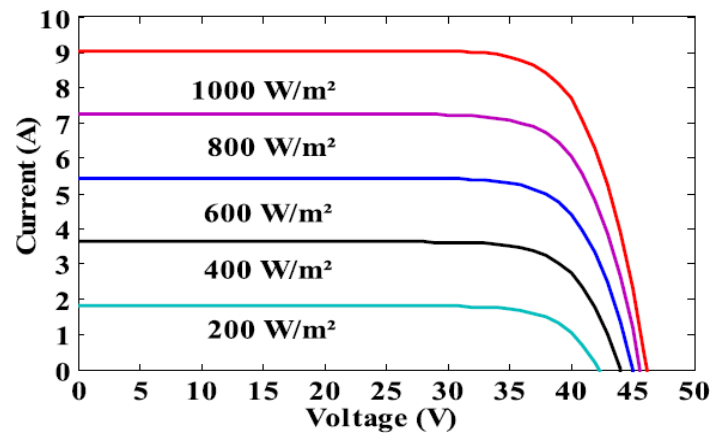

Figure 9: P-V characteristics, varying solar radiation at Constant temperature

The temperature demonstrates a significant effect on the output performance of PV solar module when irradiance intensity is kept constant at 1000 $\mathrm{W} / \mathrm{m}^{2}$. In current characteristics, minor variation is observed when the temperature varies from $10^{\circ}$ $\mathrm{C}$ to $70^{\circ} \mathrm{C}$. The voltage value shows increasing trend in $\mathrm{I}-\mathrm{V}$ performance curve when the atmospheric temperature reduces as shown in Figure 10.

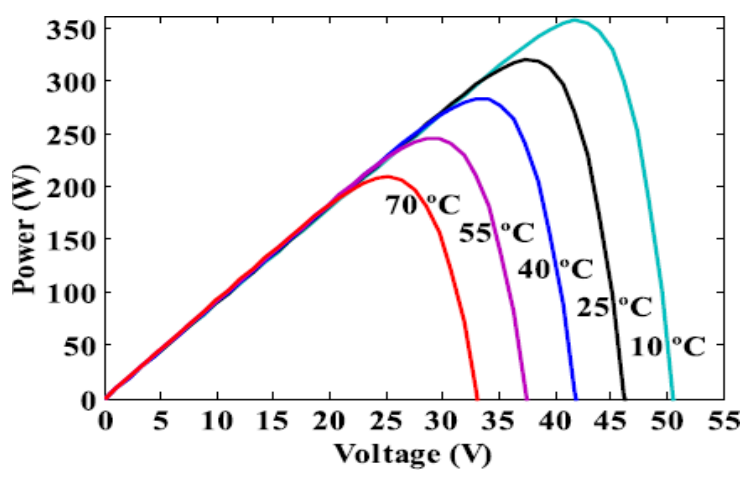

Figure 10: I-V characteristics, varying temperature at constant solar radiation.

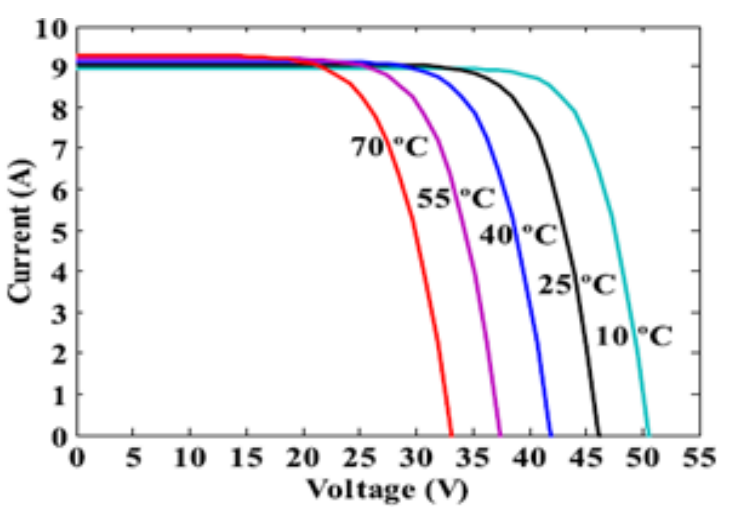

Figure 11: P-V characteristics, varying temperature at Constant solar radiation 
Also PV solar cell generates more power when the atmospheric temperature reduces as shown in Figure 11. So, solar cell shows inverse relationship with temperature.

\section{Conclusions}

Based on the simulated results of the present work, the following interpretations are derived.

- Hybrid Solar Cell is more effective and efficient compared to the individual PV cells and DSSCs.

- The power generated from the Hybrid solar cell is independent of the time in a day.

- Efficiency of the Hybrid Solar cell can be increased by changing the individual dye as well with combination.

- Air and Noise pollutions can be reduced by the use of Hybrid e-Vehicle.

- The e-Vehicle can be charged throughout the day.

\section{References}

[1] B.H.Khan, Non Conventional Resources, TMH publisher, 2007.

[2] RB Gupta, Automobile Engineering, Satya Prakashan, 4th Edition, 1984.

[3] Gratzel M. Dye-sensitized solar cells, Journal of photochemistry and Photobiology C: Photochemistry Reviews, Volume 4, Issue 2, October 2003, 145-153.

https://doi.org/10.1016/S1389-5567(03)00026-1

[4] Kumari, J.M.K.W.; Sanjeevadharshini, N.; Dissanayake, M.A.K.L.; Senadeera, G.K.R.; Thotawatthage, C.A. The effect of $\mathrm{TiO} 2$ photo anode film thickness on photovoltaic properties of dye-sensitized solar cells. Ceylon J. Sci. 45, 2016, 33-41.

[5] J. J Uicker (Jr), G. R Pennock and J. E Shigley, Theory of Machines and Mechanisms, 3rd Ed., Oxford International Student Edition, 2009.

[6] MATLAB/SIMULINK software, Mathworks.

[7] Engineering Graphics, KR Gopalakrishna, 32nd Edition,Subhas publishers, Bangalore, 2005

[8] Syafinar R, Gomesh N, Irwanto M, Fareq M and Irwan $\mathrm{Y}$ M(2015), Potential of Purple Cabbage, Coffee, Blueberry and Turmeric as Nature Based Dyes for Dye Sensitized Solar Cell (DSSC), Energy Procedia, Vol. 79, Nov. 2015, 799-807.

[9] Syafinar R, Gomesh N, Irwanto M, Fareq M and Irwan Y M (2015), Chlorophyll Pigments as Nature Based Dye for Dye- Sensitized Solar Cell (DSSC) Energy Procedia, Vol. 79, Nov. 2015, 896-902.

[10] Cahya E, Universitas P, Indonesia P, Sensitized A D, Cell S, View S I and Prima E C, Simulation of Dye-Sensitized Solar Cells (DSSC) Performance for Various Local Natural Dye Photosensitizers, International Conference on Condensed Matters and Advanced Materials (IC2MAM 2018), Universitas Negeri Malang, Malang, Indonesia., 2018

[11] Tayyan A A El, Dye sensitized solar cell: parameters calculation and model integration, Journal of Electron Devices, Vol.11, 2011, 616-24,

[12] W.Bolton, Longman, Mechatronics, 2nd Edition, Pearson Publications, 2004. 